\title{
CLIMATE CHANGE VULNERABILITY AND NATION-BUILDING: THE MFOM II- OGOJA EXPERIENCE
}

\author{
PATRICK O. ODEY \\ DEPARTMENT OF HISTORY/INTERNALTIONAL STUDIES \\ UNIVERSITY OF CALABAR, CALABAR
}

\begin{abstract}
The anthropogenic activities of man like bush burning, use of chemicals, deforestation, overgrazing, and fumes from automobiles, generating sets over time have depleted the Ozone shield and adversely affected the climate. Climate variables like temperature, rainfall, sunshine and wind have changed considerably, as there have been cases of delayed and early stopping of rain, flooding and drought, late planting of crops and poor yield. The study area is Mfom II, an Ekajuk community of Ogoja Local Government Area of Cross River State. The Mfom II people are agrarian with part-time fishing and hunting activities as a result of their geographical location in the upper fringes of the Cross River. Climate change has negatively impacted on the people's source of food security and income. The study intends to capture the factors that made the area vulnerable to climate change and the nexus between the impact of climate change and nationbuilding. Materials for this endeavour were gleaned from interviews with farmers on their awareness of the climate change phenomenon, their adaptability strategy(ies), and validated with published literature on the subject. It is argued that vigorous extension services, availability and affordability of farm inputs, improvement on the knowledge of available alternative sources of fuel to mitigate climate change vulnerability, improve agricultural productivity and environmental sustainability toward achieving nation-building would be factors to reckon with.
\end{abstract}

Keywords: Climate Change, Mfom II, Ogoja, Vulnerability, Nation-Building

\section{INTRODUCTION}

Man has significantly interfered with nature since sedentary life became possible. This interference is incremental following the improvement in technology towards satisfying needs and aspirations of the ever increasing demography of the society. From the simple stage of subsistent food grower to mechanized agriculture utilizing chemicals for soil fertility and weeds control. From the habitation of small homesteads to mansions with sophisticated architectural designs. From rudimentary industries to ever-innovative industries emitting killer fumes to the 
International Journal of Arts and Humanities

ISSN: 2581-3102

Volume: 04, Issue: 06 "June 2020"

environment disastrous to the fauna and fora. These sum up the anthropogenous activities of man in his frantic attempt to control his environment. The German Catholic Bishops argued, "Just a few decades ago, anthropogenic global climate change, i.e. that caused by human activity, was considered a possible event in the distant future. Today, it must be under-stood as a process that has already begun and is extensively changing the living conditions on Earth." ${ }^{\prime 1}$ Indeed that once distant future is here and the dooms day is with us.

It is trite to state that the Ozone layer has been depleted and the climate has changed overtime. The socio-economic categorization of the society into urban and rural notwithstanding, the impact of the climate change phenomenon is apparent. It is the vulnerability of climate change that becomes ruralised, the spatial impact occasioned by socio-economic variables. The Johannesburg Declaration on Sustainable Development Report describes the vulnerability of developing countries to climate change thus: "the adverse effects of climate change are already evident, natural disasters are more frequent and more devastating and developing countries more vulnerable." 2 The vulnerability of countries is apparent in developing countries due to poverty, hence, "while climate change is a global phenomenon, its negative impacts[sic] are more severely felt by poor people and poor countries because of their high dependence on natural resources, and their limited capacity to cope with climate variability and extremes." ${ }^{3}$ Africa remains one of the most vulnerable continents to climate change because of multiple stresses (resulting from both political and economic conditions), the continents dependence on natural resources and its weak adaptive capacity. ${ }^{4}$ The Food and Agricultural Organization(FAO) conceives climate change as the day-to-day fluctuations in atmospheric conditions of the earth's lower surface within a geographically defined location. The essential climatic variables that fluctuate include: temperature, precipitation, atmospheric pressure and humidity, wind, sunshine and cloud cover. ${ }^{5}$ These changes are triggered by a long period of sustained interference with the environment by man and the reaction of the environment to these interferences. At the global stage, the activities of the industrialized nations have saturated the lower atmosphere with

\footnotetext{
${ }^{1}$ The German Bishops Commission for Society and Social Affairs, Commission for International Church Affairs. "Climate Change: A Focal Point of Global, Intergenerational and Ecological Justices. An Expert Report on the Challenges of Global Climate Change" No. 29en, September 2016, 11. www.catholicclimatecovenant.org/cat... Accessed June 26, 2017.

${ }^{2}$ Cited in A. A. Ekwe et.al. "Agricultural Innovations for Climate Change Adaptation and Food Security in West Africa: The Case of Nigeria, Sierra Leone and Liberia," African Technology Policy Studies Network Working Paper Series, No. 61, 2011, p. 9.

${ }^{3}$ Cited in Ekwe et.al. p. 9.

${ }^{4}$ Cited in Ekwe et.al. p. 10.

${ }^{5}$ Cited in Gushibet Solomon Titus. "Climate Change and Food Security in Nigeria: Regression Analysis." Journal of Research and Contemporary Issues (JRCI) Vol. 6, Numbers 1\&2, January-December 2011, p. 29.
} 
International Journal of Arts and Humanities

ISSN: 2581-3102

Volume: 04, Issue: 06 "June 2020"

greenhouse gases generated from combustible fossil fuel and deforestation. As an irony of fate, these industrialized nations are less impacted by the effect of industrialization.

The Intergovernmental Panel on Climate Change $4^{\text {th }}$ Assessment Report 2007 revealed that "between 75 and 250 million people may be exposed to increased water stress due to climate change by 2020 in Africa and this will adversely affect livelihood in the region." ${ }^{6}$ The result of this change in climate indicates significant changes in soil fertility for agricultural activities, alteration in the time of the usual farming operations- land preparation, cultivation(planting), growing, yield, harvesting, and storage. Ekwe et.al. argues that yields from rain-fed agriculture in some countries could be reduced by up to $50 \%$. Thus, climate change may have particularly serious consequences in Africa, where some 800 million people are undernourished. ${ }^{7}$ Climate change therefore, affects agricultural productivity and food security. R. Green identified seven groups of persons highly vulnerable to food insecurity:

- Victims of sustained drought and/or ecological degradation whose previous sources of income (herds, seed stock, land improvements) have been wiped out;

- Land-hungry migrants- often poor women-headed households- who move into marginal land(in terms of soil, weather, ecological fragility);

- Isolated or peripheral rural people at the ends of marketing administrative and supply lines;

- Small producers who are self-provisioning, but also sell food for cash income;

- Victims of war;

- Members of the urban informal sector who cannot match high urban prices with low income and live in crowded, poorly serviced slum or exurban areas;

- Urban wage earners whose purchasing power has fallen dramatically in the last decade. ${ }^{8}$

The fourth category appropriately matches the Mfom II people who are ruralized rain-fed food crops farmers. Their farming activities are determined by the raining season which starts between late March and April as a result of climate shift within the last decade.

The search for nation-building immediately after independence has been frantic especially in view of failed expectations from the various indigenous governments as a result of poor leadership, nationality question, the Civil War, corruption, poverty, illiteracy, gender discrimination, insurgency, environmental degradation, climate change and food

\footnotetext{
${ }^{6}$ Cited in Agwu Agwu Ekwe et.al. 10.

${ }^{7}$ Cited in Agwu Agwu Ekwe et.al. 10.

${ }^{8} \mathrm{R}$. Green in Ben Wisner. "Health of the Future/the Future of Health." In Towards A New Vision of Self-Sustainable Development, edited by Ann Seidman and Frederick Anang. (Trenton: Africa World Press; 1989), p. 151.
} 
International Journal of Arts and Humanities

ISSN: 2581-3102

Volume: 04, Issue: 06 "June 2020"

insecurity. ${ }^{9}$ There is a nexus between climate change vulnerability and Nation-building. While the former has to do with the unfriendly interference of man in the environment that impact negatively on the surroundings, health of citizens, and economy. The latter is posed to chart a new course towards ameliorating or mitigating these challenges to guarantee sustainable livelihood for the citizenry.

\section{Mfom II: A Brief}

The Mfom II community is one of the Ekajuk communities of Ogoja Local Government Area of Cross River State. This Ekajuk people with the Nkim and Nkum presently constitute the Ejagham of Ogoja. ${ }^{10}$ It is located with Mfom I in-between Okpoma and Yahe of Yala Local Government Area of Cross River. Strategically, Mfom II is located at a junction that links the Ikom-Abakaliki road to the right and the Okuku-Abakaliki road to the left, when accessed from Yahe. The following settlements make up Mfom II- Abuja, Adigbo, Agbu, Ajina, Akpunghu, Ekaduna, Echititi, Monkom, Ngulya, and Ntimkim. The Mfom II people are predominantly subsistent farmers who grow food crops like yam(king crop), cassava, rice, maize, groundnut, and melon. They engage in livestock rearing for income and improved protein intake. Fishing, hunting and trading were part of the economic activities of the Mfom II people. It should be noted that both fishing and hunting were majorly on part-time basis because these activities were seasonal (during the dry season) when farming activities had been concluded.

The excess farm produce were usually sold in the market or along the major roads due to the strategic location of the community. Traders from neighbouring communities and States of the Federation and also travellers using the section of the trans-Saharan road from Enugu through Mfom II to Ikom up to the Republic of Cameroon, find Mfom II a delight for garri, rice and yam. Their economic activities flourished due to their geography that provided them with fertile lands and the Aya River which waters the riverine areas. However, the repeated farming activities, demographic pressure, use of chemicals, bush burning, flood and drought, and greed for materialism by some of the inhabitants of the community have denied the farmers bountiful harvest, income, and caused poor health. It is on this score, that attention will be focused on the causes of climate change vulnerability in Mfom II.

\section{Causes of Climate Change Vulnerability and Impact}

Acknowledging the vulnerability of man globally:

\footnotetext{
${ }^{9}$ See D. L. Imbua, S. O. Onor, and P. O. Odey, A Companion to African History in the Nineteenth and Twentieth Centuri,. Makurdi: Aboki Publishers; 2017.

${ }^{10}$ Onor, The Ejagham Nation in the Cross River Region of Nigeria. Makurdi: Aboki Publishers, 2016, p. 97. 


\section{International Journal of Arts and Humanities}

ISSN: 2581-3102

Volume: 04, Issue: 06 "June 2020"

Climate change currently represents probably the greatest existential threat for present and future generations as well as for non-human nature. Consequently, it presents a serious challenge to the responsibility for creation. How humans interfere with the climate system, with global impact, and how this in turn affects the biological, social and spatial existential basis is becoming ever more apparent. $^{11}$

What the Mfom II people suffer like elsewhere is man-induced. Naturally, Carbon dioxide $\left(\mathrm{CO}_{2}\right)$ is exchanged continually in a circle between the atmosphere, plants and animals through photosynthesis, respiration, and decomposition, and between the atmosphere and the ocean through gaseous exchange. Sustained deforestation and the use of fossil fuels have adversely disrupted the carbon circle. This is due largely to disproportionately slower rate to naturally balance the process of restoring the carbon circle to the higher rates at which human activities have added $\mathrm{CO}_{2}$ to the atmosphere. ${ }^{12}$

The emissions accumulate overtime and impact negatively on the environment. This is because man is a major geomorphic agent capable of changing the environment faster than the natural process. ${ }^{13}$ The teeming population, the quest for cultivable and construction lands, and the demand for forest products like timber, have caused deforestation. For instance, when the forests are depleted for timber and farming, the natural vegetation is lost and the environment is exposed to heat waves. Bush burning is still common practice among the poor rural farmers. Egre Ntul, argues while clearing the bushes, "I am aware of the climate change phenomenon. I clear my bushes and burn them so that the soil can derive some nutrient." ${ }^{14}$ Burning of bushes by either accidental(natural) or controlled(anthropogenic) fires to begin the farming season or for hunting may fasten the growth of fresh grasses, exterminate pests and provide bush animals for sources of protein and income when sold. It is a hazardous exercise or practice usually tolerated with caution so as to encourage yield. The burdens of anthropogenic climate change are spread very unevenly. The poorest are affected most by this change, both globally as well as within individual countries. The poor countries of the South, particularly, which only contribute very

\footnotetext{
${ }^{11}$ The German Bishops Commission for Society and Social Affairs, Commission for International Church Affairs. "Climate Change: A Focal Point of Global, Intergenerational and Ecological Justices. An Expert Report on the Challenges of Global Climate Change" No. 29en, September 2016, 11. www.catholicclimatecovenant.org/cat... Accessed June 26, 2017.

12 The Royal Society. "Climate Change. Evidence \& Causes: An Overview from the Royal Society and the US National Academy of Science"2014, 3. royalsociety.org/topics-policy. Accessed June 28, 2017.

${ }^{13}$ G. Y. Jamala, P. G. Boni, and C. P. Teru. "Evaluation of Environmental and Vulnerability Impact of Bush Burning in Southern Guinea Savanna of Adamawa State, Nigeria."American Journal of Experimental Agriculture 2(3), 2012, 360. www.taccire.suanet.ac.tz/xmlui/bits.Accessed July 2, 2017.

${ }^{14}$ Egre Ntul. 57, Farmer, Interview at Ngulya- Mfom II, December 2, 2016.
} 
International Journal of Arts and Humanities

ISSN: 2581-3102

Volume: 04, Issue: 06 "June 2020"

marginally to the causes, have difficulties adapting to the changes. The industrial nations, by contrast, which are essentially responsible for the emission of climate-damaging green-house gases, are much more able to protect themselves against the consequences. This great inequality between polluters and victims makes anthropogenic climate change into a fundamental problem of global justice. Indeed, there is also a time dimension to this inequality. Our failure to protect the climate today will above all develop its negative effects in the future, since the greenhouse gas carbon dioxide (CO2), in particular, remains in the atmosphere for several decades as a result of which its negative impact is time-delayed. This in turn calls the principle of intergenerational justice into question. Beyond the interests of the poor and of coming generations, climate change eventually fundamentally affects the habitats of fauna and flora as well and so impacts the relationship between humans and their fellow creatures. ${ }^{15}$

Bush burning is a major source of air pollution with the emissions like, carbon monoxide, carbon dioxide, nitrogen and sulphur oxides. These oxides inflict respiratory disorders that the proceeds of the initial action cannot manage. The impact just like the greenhouse gases emitted by the industrialized countries are not directly affected or have the awareness and resources to mitigate the consequences of their actions, those in the Third World and Mfom II particularly are vulnerable. The soil is destroyed, wildlife and forest depletion, especially when the fire becomes uncontrollable. Farmlands and barns are destroyed, buildings are burnt, surroundings are littered with the residues of the burnt materials, fruit trees like mango, cashew, oranges are destroyed. In sum, the fire destroys the environment, health hazards, reduces soil fertility, destruction of cash and food crops viability and increases poor yield which causes hunger, poverty, and conflict(and possible arrest and prosecution).

The activities of illegal fuel vendors (black marketers) who capitalize on the failed institution to adulterate and sell Premium Motor Spirit(PMS) to the public. This adulterated product is used to power automobiles, motorcycles, and generating sets. The epileptic power situation in Nigeria and the rural Mfom II in particular have increased the demand for and use of smaller generating sets popularly known as I Pass my neighbour. The fume from these generators are hazardous to both man and the environment. The failure of government to address the issues of petroleum products, power generation and utilization coupled with greed by citizens at the grassroots have polluted the environment and caused health challenges to man.

\footnotetext{
${ }^{15}$ The German Bishops Commission for Society and Social Affairs, Commission for International Church Affairs. "Climate Change: A Focal Point of Global, Intergenerational and Ecological Justices: An Expert Report on the Challenges of Global Climate Change" No. 29en, September 2016, 13. www.catholicclimatecovenant.org/cat... Accessed June 26, 2017.
} 
International Journal of Arts and Humanities

ISSN: 2581-3102

Volume: 04, Issue: 06 "June 2020"

The reduced soil fertility as a result of continuous use and the impact of bush fire, have caused farmers to acquire and utilize chemicals as fertilizers, herbicides, and pesticides. The loss of or dwindling soil fertility and need to rejuvenate it, and the rampaging activities of pests have increased the use of chemicals and recently. Lending a voice to the use of inorganic fertilizer and pesticides in agricultural activities, Uzo Igbozurike argued, "of these already vast range, and the number of patented labels increases by the week in the industrialized countries, with the 'spread effects' penetrating overnight to the relatively remote backwaters of the world- no matter how piecemeal. ${ }^{16}$ The statistics on fertilizer and other anti-pests and weeds chemicals use have soared over time. In the study area like elsewhere within the agrarian belt of Cross River State, the paucity of fund to pay for the high cost of labour has made the choice of chemical use preferable. Labour, has increasingly become scarce and the very few hands charge a fortune and sometimes are not reliable in terms of prompt delivery of service. Raymond Etuji asked, "What choice is left to a farmer like me?" since, "chemicals! I buy and apply them myself." ${ }^{17}$ Most young men have abandoned farming and the labour supply for schooling, other economic activities like commercial motorcycling (Okada) to make quick money, and the last recourse to vices(political thuggery and cultism). The chemicals used in the farms pollute the water when washed by the rains. From the pictures shown on Plates 1-3, the Aya River and the swamp provide water sources for the Mfom II people. The people are rather exposed to water-borne diseases.

Absence of accessible extension services have left Mfom II farmers uninformed of adaptation measures to climate change and further aggravated climate change. Farmers continued with bush burning and chemical use to "improve" agricultural production. Extension services are fundamental for sharing new knowledge generated from research with farmers for the benefit of agricultural productivity, increasing food security and improving rural livelihoods. If done effectively, this farmer education support could enable them to optimize the use of limited resources, overcome new agricultural challenges and work as a driver of pro-poor economic growth. $^{18}$

\section{Climate Change Mitigation and Adaptation}

The two fundamental response options to the risks posed by anthropogenic climate change are mitigation of climate change and adaptation to it. Mitigation refers to limiting global climate change through reducing the emissions of greenhouse gases (GHGs) and enhancing their sinks.

\footnotetext{
${ }^{16}$ Uzo Igbozurike. Agriculture at the Crossroads. A Comment on Agricultural Ecology. (Ile-Ife: University of Ife Press; n.d),43-44.

${ }^{17}$ Raymond Etuji. 70. Farmer, Interviewed at Mfom I, December 1, 2017.

${ }^{18}$ Ann Kingiri. "Gender in Extension Approaches" TECHNOPOLICY AFRICA October-December 2015, 11. www.atpsnet.org. Accessed June 7, 2107.
} 
International Journal of Arts and Humanities

ISSN: 2581-3102

Volume: 04, Issue: 06 "June 2020"

Adaptation primarily aims at moderating the adverse effects of unavoidable climate change through a wide range of actions that are targeted at the vulnerable system (It may also include taking action to seize new opportunities brought about by climate change). ${ }^{19}$ Mitigation has traditionally received much greater attention than adaptation in the climate change community, both from a scientific and from a policy perspective. Important reasons for the focus on mitigation are, that mitigating climate change helps to reduce impacts on all climate-sensitive systems, whereas the potential of adaptation measures is limited for many systems. ${ }^{20}$ However, the Mfom II community is limited in the effectiveness of her indigenous adaptation mechanism in terms of impact avoided and or availability and accessibility to external interventions from the State, Federal Governments and international bodies. The last flood of 2016 that destroyed farms and crops, no relief materials got to the victims.

Many climate change adaptation efforts aim to address the implications of potential changes in the frequency, intensity, and duration of weather and climate events that affect the risk of extreme impacts on human society. ${ }^{21}$ Cross River State within which Mfom II is located in the northern fringes, has a high vulnerability index. The Mfom II people are aware of the changed climate and the effect on their socio-economic and political lives. Their adaptive capacity is determined considerably by education/information, assets, and income. ${ }^{22}$ The people have developed adaptation mechanism corresponding to the level of their awareness, technology, socio-cultural and economic realities. They have a task force in place to regulate the harvest of river sand, fishing technique (to check any epidemic resulting from the use of poison to fish), bush burning, and logging. While this environmental conservation measure is commendable, the presence of some deviants and greedy individuals, the effort has often been undermined. Harvesting of rain water in several troughs, sinking of wells, water from streams and swamps, and recourse to water vendor as shown on Plates 1-3 below were embarked on so as to ease the mounting tension.

\footnotetext{
${ }^{19}$ Hans-Martin Fusseland R. J. T. Klein. "Climate Change Vulnerability Assessments: An Evolution of Conceptual Thinking” Climate Change75, 2006, 303. DOI: 10.1007/s10584-006-0329-3 _

${ }^{20}$ Hans-Martin Fussel and R. J. T. Klein, p. 304.

${ }^{21}$ Omar-Dario Cardona, et.al. "Determinants of Risk: Exposure and Vulnerability" www.ipcc.ch/../SREXChap2 FINAL.pdf. Accessed July 2, 2017.

${ }^{22}$ See I. A. Madu. "Rurality and Climate Change Vulnerability in Nigeria: Assessment Towards Evidence Based even Rural Development Policy.” Being a paper presented at the 2016 Berlin Conference on Global Environmental Change Held from 23-24 May 2016 at Freie Universität Berlin 2016, p. 15.www.diss.fu-berlin.de/docs. Accessed May 20, 2017.
} 
1.

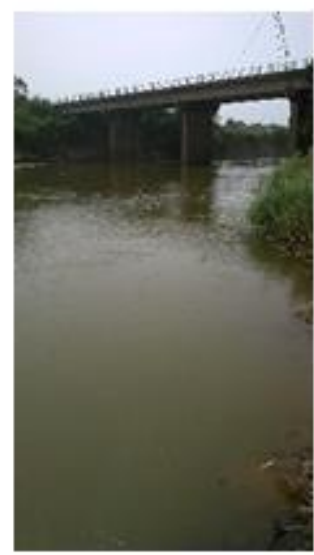

2.

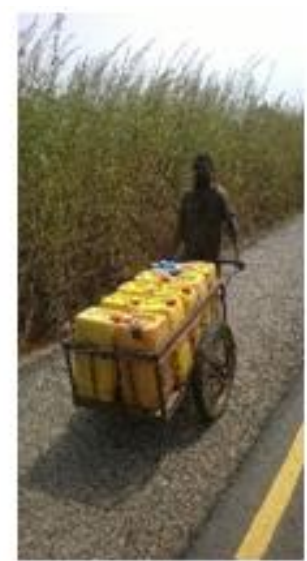

3.

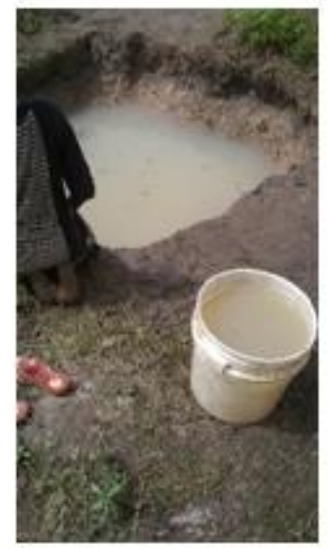

Plate 1: Aya River, a major source of water for domestic and fishing activities.

Plate 2: Water vendor supplying water from the Aya River.

Plate 3: A woman fetching water from a rice swamp

\section{Source: Field pictures at Ngulya, Mfom II, December 2, 2016.}

There is need for sincerity on the part of government in her commitment to mitigate the impact of climate change. A situation where extension services are unavailable to the farmers on best farming practices congruent to their peculiarities in terms of socio-economic realities frustrates the farmers' adaptation and mitigation efforts. Climate change is evident in every continent, especially now that it is man-made. Much has been said with very little actions from top to bottom just as there are fragile or no links between government and the grassroots. The agrarian Mfom II people have age grades and cooperative groups that could serve as conduit for climate change adaptive enlightenment but have not been used. Constituting climate change ambassadors within the existing socio-cultural and religious groups will fill the lacuna created by the poor extension service. The construction and maintenance of irrigation systems, the use of chemicals to kill weeds instead of weeding, and application of inorganic fertilizers to improve soil fertility have all been expensive to procure. In a bid to ameliorate this challenge, community self-help groups should be formed to lighten the financial burden of acquiring and maintaining water pumps, rather than waiting endlessly for a non-responsive government.

Recall that these farmers have recorded low yield previously, then other financial obligations would naturally strip them of the necessary financial buoyancy to venture into these modern innovative practices. A respondent divulged that they have filled forms for the umpteenth time for assistance from government through the instrumentality of their cooperative but the politicians have deliberately frustrated them by hijacking the intervention scheme to fund their 
International Journal of Arts and Humanities

ISSN: 2581-3102

Volume: 04, Issue: 06 "June 2020"

other private businesses. ${ }^{23}$ This has left the farmers to rely on their meagre income to adapt to climate change. There was a unanimous response to the government non-responsiveness to the victims of 2016 flood incident that destroyed their farms leading to poor productivity. A glance at the rice fields on Plate 4 is evident. The template drawn by the Conference of Parties(COP) 18 held in Doha, to determine the range of options for the assessment of loss and damage if adopted by all stakeholders involved in the mitigation and adaption to climate change will be imperative in the Mfom II case and elsewhere. These include:

a. Promoting an enabling environment to encourage investment and the involvement of relevant stakeholders in climate risk management;

b. Involving vulnerable communities and populations, civil society, the private sector and other relevant stakeholders in the assessment of and response to loss and damage; and

c. Enhancing access to, and sharing and use of, data, such as hydro-meteorological data and metadata, on a voluntary basis, to facilitate the assessment and management of climate-related risk. ${ }^{24}$
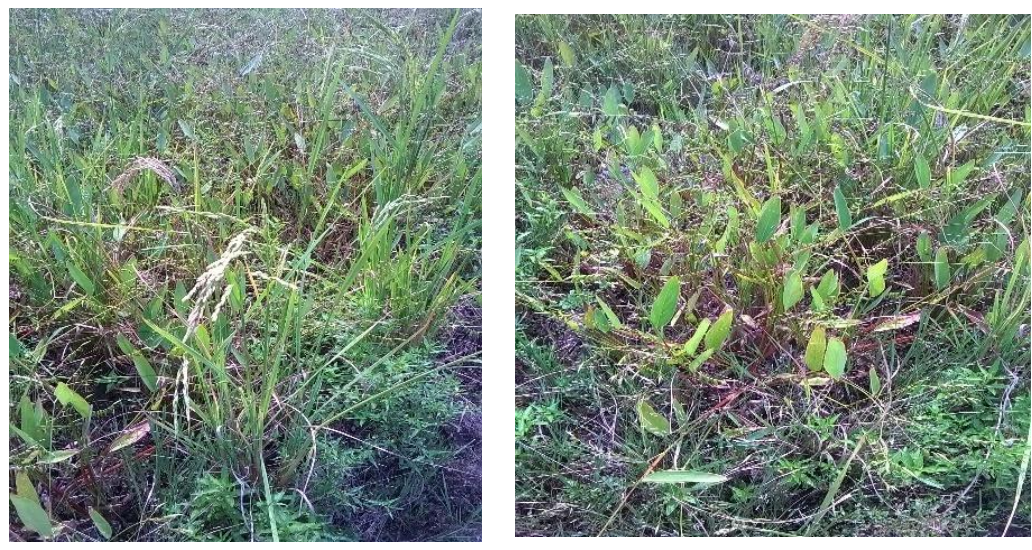

\footnotetext{
${ }^{23}$ Moshe Edi. 45 years, Farmer, Interviewed at Mfom II, December 2, 2016.

${ }^{24}$ The World Bank. Building Resilience: Integrating Climate and Disaster Risk into Development. The World Bank Experience. (Washington DC: International Bank for Reconstruction and Development/ The World Bank; 2013),2. documents.worldbank.org. Accessed July 2, 2017.
} 


\section{International Journal of Arts and Humanities}

ISSN: 2581-3102

Volume: 04, Issue: 06 "June 2020"

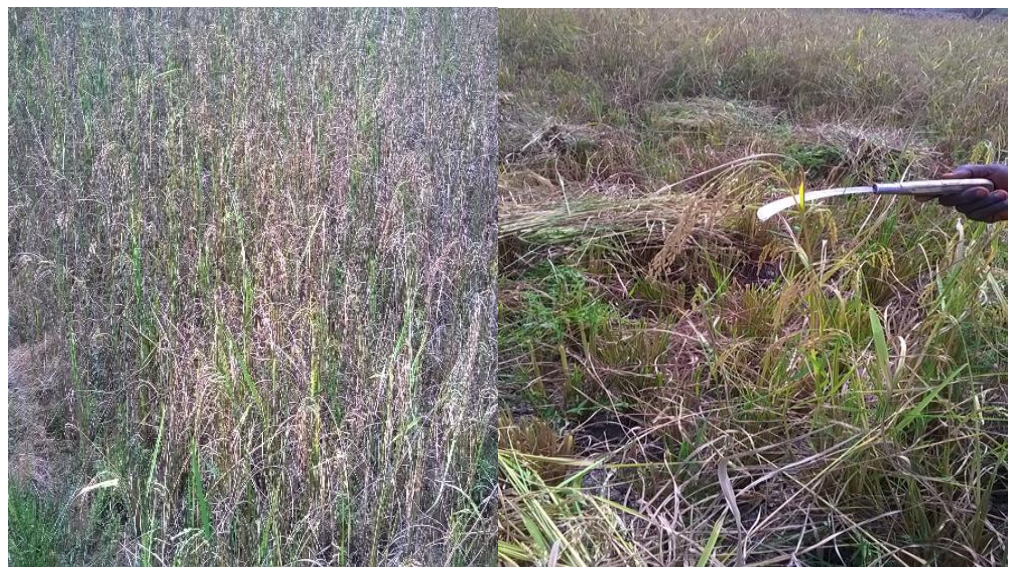

Plate 4: Rice farms devastated by flood and infested by weeds at Ngulya, Mfom II

Source: Field pictures, December 2, 2016

There is urgent need for concerted efforts from traditional and religious leaders, age grades, schools, extension officers and faith-based groups to intensify efforts at reaching out to farmers and other members of the society on the anthropogenic activities and the modern adaptive measures to mitigate the adverse effects of climate change. The quotes of three Catholic Pontiffs are apt. Emeritus Pope Benedict XVI in an address asked, "[H]ow can we separate, or even set at odds, the protection of the environment and the protection of human life, including the life of the unborn?"25Pope Benedict XVI ventilated the position of the Catholic Church as an express mandate from God to man for the protection of both the environment and the sanctity of the human life, even that of the unborn. This is because from creation, God created the environment and put man in it with specific instruction to tend it. Any harm to the environment by man is injurious to man and an offence to God. In a similar vein, the Pope Saint John Paul II reminded the congregation in a 1990 World Day of Peace message:

I should like to address directly my brothers and sisters in the Catholic Church, in order to remind them of their serious obligation to care for all of creation. The commitment of believers to a healthy environment for everyone stems directly from their belief in God the Creator, from their recognition of the effects of original and personal sin, and from the certainty of having been redeemed by

\footnotetext{
${ }^{25}$ Pope Benedict XVI, Address to the Diplomatic Corps, January, 11, 2010. Culled from John Cole and Frank Incropera. "A Catholic Perspective on Climate Change" Drought and Food Production in Ethiopia. Courtesy Catholic Relief Services (Climate Change and Global Solidarity towards a Sustainable Energy Future- Policy Brief, September 14, 2015), 3.www.crs.org/sites/default/files/ex1... Accessed June 29, 2017.
} 
International Journal of Arts and Humanities

ISSN: 2581-3102

Volume: 04, Issue: 06 "June 2020"

Christ. Respect for life and for the dignity of the human person extends also to the rest of creation, which is called to join man in praising God (cf. Ps 148:96). ${ }^{26}$

To the substantive Pope Francis, describes climate change resulting from human activities as an ecological crisis urgently requiring an ecological conversion and:

a summons to profound interior conversion. It must be said that some committed and prayerful Christians, with the excuse of realism and pragmatism, tend to ridicule expressions of concern for the environment. Others are passive; they choose not to change their habits and thus become inconsistent. So what they all need is an "ecological conversion", whereby the effects of their encounter with Jesus Christ become evident in their relationship with the world around them. Living our vocation to be protectors of God's handiwork is essential to a life of virtue; it is not an optional or a secondary aspect of our Christian experience. ${ }^{27}$

Pope Francis advocated morality in the conduct of human activities in the environment through education from the family, worship centres, socio-cultural groups and the schools.

\section{CONCLUSION}

Climate change is man-induced(anthropogenic).Man has variously interfered with the environment through deforestation, bush burning, chemical use, use of fossil fuel, and fumes from automobiles and generating sets powered by adulterated fuel. These activities have adversely impacted on the fertility of the soil, availability of soil water and contamination of water for domestic use, poor crop yield, health challenges, low income, malnutrition, and a potential for land dispute in the future. The Mfom II people, aware of climate change have innovated some indigenous adaptation mechanism like constituting a taskforce on the regulation of river sand harvesting, logging, fishing, and bush fire. At individual levels, the farmers have been engaged in bush fallowing, multi-cropping, rain water harvesting, and planting of diseaseresistant crops.

Also they have used fertilizers and chemicals that have improved crop yield and killed pests and weeds. Their crops have tasted different and cannot be stored for longer periods, a condition that has been at variance with what was two decades earlier when chemicals were not used. These

\footnotetext{
${ }^{26}$ Pope Saint John Paul II, World Day of Peace Message, No. 6, January 1, 1990. Culled from John Cole and Frank Incropera. p. 3.

${ }^{27}$ Pope Francis, Laudato si'(Encyclical Letter of the Holy Father Francis on Care for our Common Home)Paragraph 217, 159. w2.vatican.va/content/dam/francesco. Accessed July 1, 2017. The environment herein is regarded as a common home, a sister, and a beautiful Mother who opens her arms to embrace us. Also see Laudato si' A Summary. www.catholic.org.au/../file. Accessed July 1, 2017.
} 
chemicals were considered harmful to their source of water when they are washed by the rain. The people have experienced drought, flood, late start and early stop of the rain, events that have impacted negatively on their farming activities, income and health.

The causes and vulnerability of climate change among the Mfom II people pose a grave challenge to nation-building in Nigeria. The welfare of the citizens- economically, environmentally, socio-culturally and politically is paramount to every legitimate and peopleoriented government. Hence, while Nigeria contributes very insignificant percentage to Green House Gases, the global concern for climate change should be domesticated at all levels of government with partnership from the people at the grassroots (the worst hit), religious, traditional, educational bodies and civil societies to become climate change ambassadors. 